\title{
CHARLES WRIGHT MILLS DAN TEORI POWER ELITE: MEMBACA KONTEKS DAN PEMETAAN TEORI SOSIOLOGI POLITIK TENTANG KELAS ELITE KEKUASAAN
}

\section{Ahmad Imam Mawardi}

Pascasarjana Universitas Islam Negeri Sunan Ampel Surabaya, Indonesia

Email : ai_mawardi@uinsby.ac.id

\begin{abstract}
Abstrak
Penelitian ini bertujuan untuk menjelaskan paradigma teori power elite oleh Charles. Wright Mills (selanjutnya, C. Wright Mills) dalam kaitannya dengan konteks pemetaan teori sosiologi politik kelas elite di Amerika Serikat. Metode yang digunakan dalam penelitian ini adalah kajian pustaka. Beberapa kesimpulan didapatkan dalam ulasan ini yaitu tiga kelompok elit politik di Amerika menurut C. Wright Mills menguasai percaturan perpolitikan dan kekuasaan yang terdiri dari elite birokrasi, elite pengusaha dan elite militer. Kedua kelas-kelas menengah dan bawah merupakan kelompok yang paling sering dieksploitasi atas kepentingan para elit dalam perpolitikan dan perebutan kekuasaan kelas di Amerika Serikat. Terakhir bahwa faktor genealogi dan faktor eksternal lainnya berpengaruh besar terhadap kelahiran dan perkembangan teori power elite yang ada di Amerika. Teori tersebut pada akhirnya bersinggungan dengan teori pluralisme yang telah lama hidup di tengahtengah penduduk Amerika. Kajian pustaka ini dapat menjadi sebuah katalisator yang menunjukkan bagaimana teori-teori politik dan sosiologi saling bersaing unutk merebut dominasi dalam percaturan perpolitikan dan kemasyarakatan, khususnya di negara maju seperti Amerika Serikat.
\end{abstract}

Kata kunci: teori power elite; pluralisme; Amerika Serikat; sosiopolitik

\section{CHARLES WRIGHT MILLS AND THE POWER ELITE THEORY: READING THE CONTEXT AND MAPPING THE POLITICAL SOCIOLOGY THEORY ABOUT THE CLASS OF ELITE POWER}

\begin{abstract}
This study aims to explain the paradigm of power elite theory by Charles Wright Mills (C. Wright Mills, henceforth) in relation to the context of mapping the political sociology theory of the elite class in the United States. The method employed in this study was library research. Based on the literature review, it is concluded that three groups of political elites in the United States according to C. Wright Mills controlled the political and power arena consisting of the bureaucratic elite, business elite, and military elite. Second, the middle and lower classes are often exploited in the interests of the elite in the politics and struggle for class power in the United States. Genealogical and other external factors greatly influence the birth and development of elite power generation in the United States. The theory is eventually in contact with the theory of pluralism that has long lived among the American societies. This literature study can be a catalyst showing how political theories and sociology compete each other to seize dominance in the political and social arena, especially in a developed country like the United States
\end{abstract}

Keywords: power elite theory; pluralism; the United States; sociopolitical 


\section{LATAR BELAKANG}

Berbicara tentang politik adalah memperbincangkan pengaruh, kekuatan dan kekuasaan (Baugut \& Scherr, 2019). Karena itulah maka politik banyak dipersepsikan sebagai "the process of who gets what, when, and how" (proses tentang siapa mendapatkan apa, kapan dan di mana). Definisi sederhana lainnya menyebut politik sebagai "the practice and theory of influencing other people" (praktek dan teori mempengaruhi orang lain) .

Istilah politik dikenalkan pertama kali oleh filosof Yunani legandaris yang sampai saat ini tetap menjadi rujukan dalam banyak hal, yaitu Aristotle. Menurutnya, politik adalah sebuah bentuk yang civilized dari masyarakat yang mengabdikan diri untuk kemaslahatan. Kata politik itu juga dalam bahasa Yunani diterjemahkan sebagai "an art of government" (seni pemerintahan) yang bertujuan untuk menormalkan pola hubungan antar kelompok sosial yang berbeda agar supaya bisa secara bersama bersepakat menentukan tujuan, bentuk dan substansi kegiatan Negara (Capano, Howlett, \& Ramesh, 2015).

Dalam perkembangannya, politik dan pemerintahan menjadi dua hal yang tidak terpisahkan. Politik menjadi bagian integral masyarakat modern dalam menata pembangunan. Politik kemudian menjadi sesuatu yang multi-dimensional; ia bukanlah sesuatu yang berdiri sendiri tanpa adanya komponen-komponen pembentuk. Sebagai sebuah sistem, politik adalah kesatuan-kesatuan dari beberapa sub-sistem, seperti partai politik, komunitas, kelas-kelas social ekonomi, ideologi dan lain sebagainya (Parker, 2005).

Keberjalin kelindanan berbagai subsistem tidak semuanya berjalan tanpa adanya konflik, karenanya maka politik tidak hanya berkaitan dengan kerjasama (cooperation) melainkan juga berkenaan dengan konflik (conflict). Konflik yang dimaksud adalah kompetisi dari kekuatan-kekuatan yang saling bertentangan yang merefleksikan opini dan kepentingan yang berbeda.

Banyaknya sub-sistem dalam struktur atau sistem politik ini membuka ruang untuk melihat dan mengamati politik dari berbagai sudut pandang, termasuk pendekatam sosiologi. Ketika sosiologi digunakan sebagai optik untuk melihat politik-- negara, legitimasi dan kekuasaan--, potret yang dihasilkan adalah beragam model atau pola perilaku sosial yang yang diduga menjadi variabel penentu terbentuknya struktur, sistem dan fakta politik. Politik itu sendiri berisikan setiap aksi yang telah melibatkan penggunaan kekuasaan untuk membentuk upaya bersama menggapai tujuantujuan bersama (Parsons, 1966).

Pertanyaan yang muncul kemudian adalah siapa sesungguhnya yang sudah mengendalikan kekuasaan, atau, dalam bahasa yang lebih tegas, siapakah sesungguhnya yang mengendalikan atau menentukan suatu kebijakan dalam suatu negara? Para sosiolog sangat tertarik mencari jawaban yang senyatanya atas pertanyaan ini, tidak bedasarkan kepada aturan dan teks undang-undang atau hukum yang ada, karena aturan dan teks hukum itu sendiri bisa jadi produk dari "siapa yang mengatur" itu. Apakah betul kekuasaan itu berada di tangan rakyat, ataukah ada di tangan segelintir orang yang mengklaim dirinya sebagai kelompok elite? (Coleman \& Donald, 1993).

Maka muncullah beberapa aliran sosiologi yang mengkaji masalah negara dan kekuasaan. Ada Marx dengan classic marxist theory, Althusser, Poulantzas, Miliband dengan contemporary marxist theorynya, Machiavelly dan Hobbes dengan teori realismenya. Aliran lainnya adalah yang dikembangkan oleh Arnold Rose, Peter Bentley, Talcott Parsons, Neil Smelser yang getol dengan teori pluralismnya, Seymour Martin Lipset, Robert Dalh dengan elite pluralismnya, Vilfredo Pareto, Gaetano Mosca, Robert Michels dengan classic elite theorynya, Weber dengan teori birokrasinya, C. Wright Mills dan W. Domhoff dengan contemporary elite theorynya dan lain sebagainya (Barrow, 2006).

C. Wright Mills merupakan salah seorang sosiolog yang cukup intens mengamati realita negara dan kekuasaan sehingga kemudian mengemukakan teori yang sangat terkenal, power elite theory. Mills tidak sendirian dengan 
teori ini, dan pengkritik teori ini juga tidaklah tunggal. Mills pun tidak sembarangan dengan teorinya; teori ini muncul berdasarkan nasab basic social theories lainnya dan sebagai respons atas sebuah konteks sosial tertentu. Tulisan ini mencoba menelusuri secara intensif dan komprehensif tentang Mills dan power elite theorynya (Alford \& Roger, 1985). Oleh sebab itu, berdasarkan paparan di atas, maka menjadi sangat penting dilakukan kajian terkait konteks dan pemetaan teori sosiologi politik tentang kelas elite kekuasaan.

\section{METODE PENELITIAN}

Fokus penelitian ini adalah tentang teori power elite yang dikemukakan oleh Charles Wright Mills. Pendekatan yang digunakan untuk mengeksplor teori di atas adalah kajian pustaka (library research) dengan membaca berbagai macam literatur dan media yang berkaitan dengan teori tersebut.

Analisis konten (Content Analysis) digunakan untuk mendapatkan data dari berbagai macam literatur yang dibaca. Selain itu, validasi data dilakukan dengan cara mencocokkan informasi-informasi yang relevan dengan beberapa sumber primer yang ada.

\section{HASIL DAN PEMBAHASAN Charles Wright Mills: Sebuah Sketsa Biografi}

Charles Wright Mills adalah seorang sosiolog Amerika yang lahir di Waco Texas tanggal 28 Agustus 1916 dan meninggal di West Nyack, New York, tanggal 20 Maret 1962. Mills dikenal sebagai pemikir radikal yang kaya gagasan, terbuka dan berani. Mills pernah menyatakan bahwa politik para intelektual adalah politik kebenaran. Inteletualharus mencari the most adequate definition (definisi yang paling tepat) dari sebuah realitas.

Atas dasar prinsip tersebut di atas maka, menurut Mills, politisasi kebenaran adalah sesuatu yang terlarang, reduksi data realitas adalah juga tindakan yang tidak diperkenankan. Kelihatan sekali dari prinsip di atas bahwa Mills sungguh berupaya untuk obyektif dalam melakukan penelitian (Mills,1963).
Rekam data pendidikannya menunjukan bahwa Mills menyelesaikan pendidikan undergraduatenya pada bidang filsafat di University of Texas at Austin pada tahun 1939, dan menyelesaikan program S3nya di University of Wisconsin-Madison pada tahun 1941 dengan bahasan disertasi tentang pragmatisme. Setelah sempat mengabdi di University of Maryland, College Park, dia kemudian menjabat sebagai dosen asisten profesor bidang sosiologi di Columbia University mulai tahun 1946 sampai masa kematiannya karena serangan jantung. Jabatan guru besar penuh baru didapatkannya pada tahun 1956. Walaupun demikian, ia tidak pernah berniat meninggalkan New York, yang diyakininya sebagai kota pendidikan (Robertson, 1988).

Karya-karyanya antara lain adalah The New Men of Power: America's Labor Leaders (1948) yang mengkaji masalah metafisika kaum buruh dan dinamika pemimpin-pemimpin kaum buruh dalam bekerjasama dengan petugaspetugas bisnis. Mills berkesimpulan bahwa kaum buruh dibungkam dengan roti dan keju sehingga kemudian menghentikan structural challenge (tantangan atau perlawanan struktural) ketika merasa nyaman menjadi bagian dari sistem. Dengan melihat pembauran mereka dalam sistem, Mills menganggap mereka sedang memainkan peranan sebagai the New Men of Power (Pendatang Baru dalam Kekuasaan) di kalangan power elites di Amerika Serikat.

Karya lainnya adalah White Collar: The American Middle Classes (1951) yang menyatakan bahwa birokrasi telah menguasai para pekerja kota, merampok segala kebebasannya dan menjadikannya semacam robot, yang senantiasa ditekan, tapi anehnya, merasa senang. Mereka mendapatkan gaji, tapi teralienasi dari dunia sosial karena tidak memiliki kesempatan dan kemampuan untuk mempengaruhi atau merubahnya (langman, 2000).

Karya yang menjadikan namanya mencuat sekali adalah The Power Elite (1956) yang menjelaskan tentang hubungan antara elite politik, militer dan ekonomi sebagai penentu kebijakan-kebijakan yang sesungguhnya. Teori 
power elite yang disampaikan dalam buku inilah yang akan menjadi kajian dalam makalah ini.

Buku lainnya yang juga sangat terkenal adalah The Sociological Imagination (1959) yang menggambarkan tentang mindset imajinasi sosiologis dalam kajian sosiologi yang menekankan pada kemampuan menghubungkan pengalaman seseorang dengan hubunganhubungan kemasyarakatan. Menurutnya, ada tiga komponen yang membentuk imajinasi sosiologis: sejarah, biografi dan struktur social (Borgatta \& Rhonda, 2000). Sociological Imagination ini memungkinkan seseorang melihat melampaui lingkungan dan personalitas lokal sampai pada konteks yang lebih luas. Karya berikutnya yang juga penting adalah: The Causes of World War Three (1958), Listen, Yankee: The Revolution in Cuba (1960), and The Marxists (1962).

Teori power elite Mills ini mendapatkan sambutan luar biasa dari para sosiolog sezaman dan sesudahnya, serta menjadi touchstone bagi perdebatan tentang strukture kekuasaan di Amerika sampai saat ini. Kalau buku-buku sebelumnya tidak banyak mendapatkan perhatian, buku The Power Elite ini menjadi mengetuk pintu dunia sosiologi untuk membukakan jalan bagi seorang Mills yang berani memaparkan realita kekuasaan dan pemerintahan Amerika lengkap dengan model skandal, koalisi dan eksploitasi massanya dengan bungkus teori soiologi politik. Sarjanasarjana seperti W. Domhoff, Miliband dan lainlain mencoba untuk menunggu data-data baru yang lebih luas sebagai bukti keberlakuan teori power elite Mills ini.

\section{TEORI POWER ELITE}

\section{Theoritical Backdrop: Pertarungan Teori- teori Sosiologi Politik}

Ketika menjelaskan fenomena politik, para sosiolog modern rata-rata menjadikan struktur sosio-politik masyarakat sebagai major focusnya. Mereka cenderung sangat peduli dengan struktur kekuasaan dan relasi-relasi kuasa yang didasarkan pada inequality (ketidaksamaan) untuk mewujudkan tujuan. Ada dua strategi yang digunakan untuk menganalisa dan menjelaskan inequality tersebut: yang pertama dan yang paling terkenal adalah teori kelas (class theory) yang secara garis besar didominasi oleh dua aliran besar, yaitu Marxist Class Theory dan Weberian (Mainstream) Theory; dan yang kedua adalah teori elite (elite theory) yang meliputi empat aliran, yaitu pluralist elite theory, elitist elite theory, democratic elitism, dan demo-elite perspective.

Aliran-aliran di atas tetap eksis sampai saat ini dengan argumennya masing-masing, bahkan beberapa teori yang muncul kemudian seringkali juga dipengaruhi atau bahkan merebahkan teori dasarnya pada teori-teori sebelumnya. Marx dan Weber adalah pioneer yang sangat berpengaruh bagi lahirnya teoriteori berikutnya, termasuk lahirnya teori power elite yang dikembangkan oleh $\mathrm{C}$. Wright Mills, yang seringkali disebut dengan teori elite kontemporer. Bagi Mills, Karl Marx dan Max Weber adalah pahlawannya yang sangat berpengaruh kental dalam teori-teori sosiopolitiknya, walaupun ia sendiri tidak pernah mengakui sebagai penganut aliran Marxist atau Weberian.

Kemunculan teori power elitenya Mills ini sebenarnya tidak bisa dilepaskan dari teoriteori elite yang muncul sebelumnya, terutama aliran yang berseberangan dengan teori Mills, yaitu aliran pluralist elite theory. Aliran inipun sebenarnya adalah perkembangan dari teori sebelumnya tentang negara dan kekuasaan. Untuk lebih jelasnya secara kronologis dapat diuraikan sebagaimana berikut ini.

a. Pluralism

Pluralisme adalah sebuah teori yang berupaya untuk menjelaskan watak dan distribusi kekuasaan pada masyarakat demokratis barat. Pluralisme klasik adalah bentuk dasar yang asli dari teori ini, tapi kemudian berkembang mengadopsi pandangan elite pluralist dalam memodifikasi teorinya yang banyak mendapatkan kritikan pedas dari para sarjana.

Pandangan dasar pluralisme memiliki kesamaan yang mendasar dengan teori fungsionalist Parsonian. Pluralisme sepakat dengan Parson bahwa power (kekuasaan) secara 
utuh berasal dari populasi secara keseluruhan, dengan anggapan dasar bahwa pemerintahan dan negara bertindak sesuai dengan kepentingan masyarakat, sistem politik negara adalah sistem pemerintahan yang paling efektif bagi penduduk untuk menggunakan power dan mengatur negara, dan penggunakan kekuasaan melalui negara adalah jalan yang paling sah dan resmi, bukan pemaksaan, karena didasarkan pada penerimaan dan kebersamaan masyarakat (Sills, 1972).

Sarjana seperti Dahl di Amerika, Hewitt, Grant dan Marsh di Inggris adalah para pendukung dari teori pragmatisme ini. Namun kemudian muncullah para pengkritik teori yang menyatakan bahwa teori pragmatisme ini memiliki banyak kelemahan, anatara lain pada metode yang digunakan untuk mengukur power dan pada bukti empiris yang yang kelihatannya berbeda dengan klaim mereka bahwa power itu menyebar pada demokrasi barat. Maka muncullah kemudian teori elite pluralism.

Teori elite pluralism ini memiliki tiga kesamaan dengan teori pluralisme klasik dalam hal bahwa masyarakat barat pada dasarnya adalah demokratis, pemerintah adalah sebuah proses kompromi, dan bahwa power secara luas tersebar di masyarakat. Namun, pada sisi lain teori tidak setuju dengan pendapat bahwa semua anggota masyarakat memiliki takaran kekuasaan yang sama, juga tidak terfokus secara eksklusif pada wajah awal kekuasaan, dan juga tidak memandang elite, pemimpin kelompok, sebagai partisipan utama dalam mengambilan keputusan. Tokoh dari teori ini adalah J.J. Richardson dan A. G. Jordan.

\section{b. Teori Elite}

Elite theory berbeda dengan pluralisme dalam hal bahwa teori elite ini memandang kekuasaan dalam masyarakat sebagai monopoli segelintir orang, small minority atau few people, yang disebut elite. Jadi, bagi elite theory, masyarakat itu terbagi menjadi the ruling class, kelas yang menguasai, dan the ruled, yang dikuasai. Pada tataran elite theory ini, para penganutnya berbeda pendapat dalam tiga hal: pertama, apakah elite ini kehendak masyarakat dan menguntungkan bagi masyarakat; kedua, apakah elite ini bersifat inevitable apa tidak; dan ketiga, mereka berbeda pendapat tentang siapa sesungguhnya yang membentuk elite itu.

Elite theory ini pertama kali dikembangkan oleh dua sarjana sosiologi Italia: Vilfredo Pareto (1848-1923) dan Gaetano Mosca (1858-1911) yang memandang bahwa pengaturan elite adalah sesuatu yang inevitable dan menghapus kemungkinan revolusi kaum buruh untuk mendirikan masyarakat komunis sebagaimana yang didengungkan oleh Marx ketika berbicara tentang kekuasaan dan negara. Bagi Pareto, elite itu menjadi elite karena memiliki ia memiliki kecakapan dan kecerdasan pribadi yang lebih dibandingkan yang lain, sementara Mosca melihatnya karena memiliki kemampuan manajemen organisasi yang lebih baik. Teori elite ini masuk dalam teori elite klasik.

Dalam perkembangannya, teori elite klasik ini dikritik oleh teori elite kontemporer yang di Amerika yang dikomandani oleh C. Wright Mills. Menarik sekali bahwa C. Wright Mills berdasarkan bukti yang terjadi di Amerika saat itu tidak percaya bahwa pengendalian dan pengaturan oleh elite ini bersifat inevitable (tidak bisa dielakkan). Mills juga menyerang pendapat Pareto yang menyatakan kekuasaan elite ini terjadi karena adanya dominasi massa oleh elite. Bagi Mills, yang terjadi sesungguhnya adalah eksploitasi massa oleh elite.

Ada perbedaan yang sangat mendasar antara "dominasi" dan "eksploitas." Mills menjelaskan bahwa massa umum dan elite adalah kelas-kelas sosial yang memiliki kepentingan berbeda, sehingga sangat mungkin muncul konflik kelas. Maka penguasaan elite atas masyarakat bawah (masyarakat umum) tidak bisa disebut sebagai dominasi, melainkan eksploitasi. Dominasi terjadi hanya jika ada kesamaan kepentingan, sementara eksploitasi terjadi karena adanya konflik kepentingan.

Maka muncullah teori power elite yang memiliki keunikan dibandingkan dengan teori elite klasik itu. Mills lebih berangkat dari teori kelas dan teori konflik yang dikemukakan oleh Marx dan Weber. Dari sinilah muncul penilaian 
bahwa Mills memang sangat dipengaruhi oleh dua pakar sosiologi tersebut.

Di samping kemunculan teori Mills ini secara kronologi geneologis intelektual dapat dilacak berawal dari kritiknya pada teori elite klasik, teori Mills ini sesungguhnya dalam konteks lebih besar adalah respon kritis terhadap dominasi aliran "pluralist" dalam kajian kekuasaan politik di Amerika. Sarjana pluralist seperti Dahl (1956), Truman (1951) dan Riesman (1950) adalah di antara sarjana yang karya-karyanya mendukung pendapat bahwa power pada masyarakat demokratik modern menyebar luas dan tidak terfokus pada satu kelompok elite, dan masyarakat melalui prosedur demokratis seperti pemilu dan lainnya menjadi subyek bersama dari kekuasaan itu sendiri.

Berbeda dengan pendapat sarjana-sarjana tersebut di atas, Mills menyatakan bahwa keseimbangan power antara kelompok yang berkepentingan sebagaimana dinyatakan kelompok pluralis itu adalah sebuah romantic ideal, cita-cita yang hanya ada di dunia imajinasi, sebab kenyataan di Amerika menunjukkan fakta bahwa eksistensi kelompokkelompok middle class, seperti kelompok petani, buruh, profesional dan lainnya berada di bawah "ketiak" kelompok kecil berpengaruh yang disebutnya power elite. Maka muncullah teori power elite yang penjelasannya dapat dipahami dalam penjelasan berikut ini.

\section{Teori Power Elite: Sebuah Penjelasan}

Teori ini berangkat dari sebuah pertanyaan "apakah betul ada kelompok elitist tertentu yang sesungguhnya mengatur Amerika?" Pertanyaan ini sesungguhnya juga dikemukakan dan diteliti oleh para sosiolog lain dengan berbagai pendekatan dan kesimpulan. C. Wright Mills membuktikan dengan penelitiannya bahwa memang ada kelompok elitis yang disebutnya dengan "elite kuasa" (power elite) yang berada dibalik semua skenario kebijakan pemerintah. Negara Amerika Serikat memang didominasi oleh kelompok informal yang jumlahnya terbatas tapi sangat kuat dan berpengaruh. Power elite ini bukanlah sebuah konspirasi, karena anggota-anggotanya tidaklah mencari kekuasaan yang luar biasa yang mereka nikmati itu, melainkan mereka itu memainkan kekuasaan itu karena mereka tengah menduduki posisi-posisi penting.

Elite kuasa ini beranggotakan orang-orang yang posisinya memungkinkan mereka menjadi lebih penting dari orang-orang kebanyakan (grass root society). Mereka adalah orang-orang yang memiliki posisi untuk memutuskan persoalan-persoalan yang memiliki konsekuensi besar. Merekalah yang memegang tongkat komando dari semua tingkatan dan organisasi di masyarakat modern. Mereka mengatur perusahaan-perusahaan besar, jalannya roda pemerintahan dan mengarahkan pembangunan militer. Mereka menduduki jabatan-jabatan yang strategis dalam masyarakat.

Jadi, power elite ini sesungguhnya tidak mesti pemegang kekuasaan formal, yakni pejabat pemerintahan, melainkan sekelompok kecil orang yang memiliki pengaruh besar untuk mengarahkan jalannya roda pemerintahan. Inilah sesungguhnya yang terjadi di Amerika. Untuk mengatakan bahwa Amerika adalah secara pasti dan utuh sebagai negara yang benar-benar demokratik adalah pendapat yang lebih banyak tidak logisnya, karena sesungguhnya masyarakatnya telah dan sedang disetup untuk kepentingan orang-orang tertentu yang mendapatkan keuntungan dari investasi yang ditanamkannya pada masyarakat.

Menurut Mills, power elite yang mengendalikan Amerika terdiri dari tiga kelompok: pertama adalah pemimpin politik tertinggi, termasuk presiden dan sedikit orang yang menjadi anggota kunci kabinet; kedua adalah pemilik dan direktur perusahaan besar; dan ketiga adalah panglima-panglima militer. Koalisi tiga kelompok elite ini akhirnya juga dikenal dengan istilah "military-industrial complex" (Mills, 1990).

Disebut dengan istilah military-indusrial complex karena dalam faktanya hubungan militer dengan pengusaha dan perusahaannya adalah sangat erat saling bahu-membahu. Para pensiunan jenderal mendapatkan posisi di kantor-kantor perusahaan yang bergerak di 
bidang kontrak pertahanan negara (militer). Para eksekutif secara bergantian memimpin perusahaan-perusahaan negara kelas atas dan perusahaan-perusahaan swasta. Anggota dewan direksi suatu perusahaan juga menjabat di dewan direksi perusahaan lain. Elite yang kaya raya ini dapat mempengaruhi kebijakankebijakan nasional dan internasional dengan cara monopoli penentuan harga, transfer uang dari satu negara ke negara lain, menaikkan atau menurunkan tingkat pekerja, memandu jalannya sistem perekonomian nasional dan lain sebagainya.

Mills menyatakan bahwa teori pluralist tidak berlaku pada power elite, ia hanya bisa berlaku pada middle sector dari sistem stratifikasi yang ada, termasuk pada Kongres Amerika, di mana satu kelompok yang kuat masih bisa berinteraksi dengan kelompok lainnya. Sementara itu kelompok power elite ini cenderung tertutup rapat dalam kesatuan mereka yang hampir saja untouchable (tak tersentuh).

Power elite ini pada biasanya terdiri dari orang-orang yang memiliki background yang relatif sama. Rata-rata mereka lahir di Amerika dari orang tua yang berkebangsaan Amerika, mereka berasal dari wilayah perkotaan, mereka rata-rata adalah penganut Protestan, dan kebanyakan mereka adalah alumni kampus Ivy League. Kecuali para politisinya, power elite ini rata-rata adalah dari wilayah Timur Amerika. Anggota-anggota power elite ini saling mengenal satu dengan lainnya dan memiliki tata prilaku, tata nilai dan tata kepentingan yang relatif sama. Mereka duduk bersama di dewan direksi perusahaan dan di jabatan pemerintahan, kemudian duduk bersama mengkoordinasikan kegiatan-kegiatan mereka.

Yang menarik di sini adalah pilihan Mills pada tiga kelompok profesi elite tersebut di atas sebagai determinant elites, sementara sesungguhnya tiga kelompok elite dalam power elite itu adalah sebagian kecil dari berbagai macam elite yang eksis di Amerika.

Setidaknya ada empat kelompok besar elite yang berhasil diidentifikasi oleh para sosiolog: pertama adalah elite politik (elite of goal attainment); kedua, elite ekonomi, militer, diplomat, dan cendekiawan (elite of adaptation); ketiga, elite yang menggunakan otoritas moral seperti rohaniawan, filosof, guru dan tokoh masyarakat (elite of integration); dan keempat adalah elite yang menjaga kesatuan masyarakat secara emosional dan psikologis, seperti para selebriti yang menjadi artis, penulis, aktor/tres terkenal, olahragawan terkenal dan lainya (pattern-maintenance elite).

Pilihan Mills ini mungkin saja didasarkan kepada fakta bahwa yang senantiasa memiliki kepentingan dengan kebijakan-kebijakan pemerintah pada saat itu adalah militer, pengusaha dan elite pemerintah itu sendiri. Secara metodologis, pilihan Mills ini sebenarnya didasarkan kepada penggunaan dua indikator kekuasaan yaitu "siapa yang mendapatkan keuntungan?" dan "siapa yang mengatur?" Jawabannya ternyata adalah power elite yang disebutkan di atas itu (Spencer, 1993).

Lebih lanjut Mills menjelaskan bahwa ada tiga level kekuasaan dan pengaruh di Amerika yang berlainan satu dengan lainnya. Level tertinggi ditempati oleh power elite yang bekerja secara informal dan dari balik layar. Mereka inilah yang membuat keputusan-keputusan besar. Level kedua adalah yang dikenal dengan middle class, beranggotakan anggota legislatif, kelompok-kelompok kepentingan tertentu, dan pemiimpin-pemimpin lokal. Keputusan pada level ini biasanya dilakukan dengan cara lobby atau prosedur legislatif, tingkat kepentingan putusannya pun di bawah yang pertama. Tingkatan yang ketiga dan terbawah adalah massa tanpa kuasa, penduduk yang tidak terorganisasi, yang pengaruhnya terhadap pengambilan keputusan yang berkaitan dengan hidup mereka sendiri sangat sedikit, dan bahkan kadang tidak menyadari adanya keputusan tersebut.

\section{The Military-Industrial Complex: Ruh Teori Elite Kekuasaan}

Kalau diamati lebih jauh, yang sangat berperan di antara tiga kelompok elite dalam power elite ini adalah militer dan para pengusaha (pemilik perusahaan). Perpaduan keduanya telah memunculkan apa yang disebut 
oleh Mills sebagai "military capitalism." Inilah yang sesungguhnya menjadi jantung power elite di Amerika; sebuah pandangan yang hampir sepenuhnya diyakini sebagai kebenaran. Meningkatnya tingkat pembiayaan pertahanan negara dan membengkaknya anggaran perang seperti yang terjadi saat ini disamping alasan keamanan negara tentu juga karena adanya ambisi-ambisi politik. Lebih dari itu adalah juga karena adanya pressure para pengusaha senjata untuk mendapatkan keuntungan bisnis dari kondisi yang ada. Pengusaha dan militer kemudian memiliki deal kelas atas untuk membuat kebijakan untuk keuntungan "bersama."

Besarnya anggaran untuk militer memang menjadi perhatian khusus banyak pengamat, terutama ketika Amerika menghabiskan pendapatan negara dengan presentasi tertinggi untuk militer, sementara Jepang dan Jerman dengan kondisi sistem ekonomi dan politik yang relatif sama menggunakannya dengan presentasi yang relatif sedikit. Pertahanan memang penting untuk masyarakat demokrasi, tapi posisi militer juga menjadi sebuah dilemma.

Penjelasan koalisi kepentingan seperti di atas itulah yang kemudian melahirkan istilah The Military-Industrial Complex, sebuah istilah yang pertama kali disampaikan oleh Presiden Dwight Eisenhower pada saat lengser dari kursi kepresidenannya, tapi kemudian dilabelkan kepada teori power elitenya Mills.

Dalam konteks negara-negara maju, kolaborasi militer-pengusaha sesungguhnya adalah hal yang biasa dan bukan hanya monopoli negara Amerika. Kekuatan yang dimunculkan oleh kolaborasi seperti ini selalu saja menempati poisisi yang sangat berpengaruh. Meskipun demikian,apa yang terjadi di Amerika adalah lebih dari sekedar berpengaruh, melainkan yang paling menentukan atas jalannya roda pemerintahan lengkap dengan pembuatan kebijakan-kebijakan pentingnya (Jennifer, 2002).

\section{Kritik terhadap teori Power elite C. Wright Mills}

Sebuah fakta yang tidak terbantahkan bahwa teori power elite $\mathrm{C}$. Wright Mill ini telah menyita banyak perhatian para pemain politik,pengamat politik dan intelektual yang giat melakukan kajian sosiologi dan politik. Salah satu faktor yang menjadikan teori ini mendapatkan perhatian luas adalah keberanian Mills melakukan kritik terbuka atas teori-teori tentang struktur kekuasaan yang dikemukakan oleh para pakar sebelumnya.

Sebuah akta yang juga tidak bisa dipungkiri bahwa tidak ada teori yang sempurna melainkan pasti memiliki celah-celah kosong yang tidak terakomodasi oleh teori itu. Teori power elite Mills ini bukanlah sebuah eksepsi. Walaupun Mills mendapatkan banyak pendukung atas teori yang dibangunnya, namun tidak sedikit para sarjana yang mengemukakan kritik kepadanya,mulai dari kritik ringan sampai pada kritik berat.

C. Wright Mill keras sekali mengkritik dan mengungkap kelemahan teori pluralism dan teori elite klasik. Setelah itu, tiba gilirannya teori power elite yang dikemukakannnya menuai banyak kritik. Meskipun demikian,tradisi kritik dalam setiap bidang kajian adalah sesuatu yang biasa yang dapat memperkaya wawasan, bukan menebarkan kebencian (Haralambos \& Robin, 2000)

Pengkritik utama Mills adalah sarjanasarjana pendukung teori pluralism yang menganggap teori power elite Mills ini sebagai teori yang tidak menghargai opini publik sembari me"tuhan"kan opini sekelompok kecil orang. Fungsi-fungsi akuntabilitas electoral politics dinafikan begitu saja, dan keuntungan pihak lain dari perbuatan power elite tidak banyak dipertimbangkan.

Hubungan power elites dan massa arus bawah tidak selayaknya dipandang hanya dari satu sisi, yakni pandangan yang mengeksploitasi dan yang dieksploitas, melainkan juga bisa dibaca sebagai relasi sosial yang bisa jadi saling menguntungkan. Pembacaan satu sisi dengan menafikan kemungkinan berbedanya potret pada 
sisi yang lain adalah sebuah kelalaian akademis yang bisa berakibat fatal (Syams, 2005).

Sebut Dahl, misalnya, sebagai pengkritik keras Mills dengan argumen metodologisnya, mengemukakan empat kritik utama yang ratarata berkaitan dengan metodologi yang dipakai Mills ketika menulis The Power Elite. Kelemahan pertama adalah bahwa Mills tidak memandang organisasi dengan cara yang netral. Keberpihakan Mills pada upper class dalam sebuah perusahaan telah membutakan Mills untuk melihat gerakan dan fungsi kaum pekerja. Konsekuensinya adalah Mills meletakkan posisi owner dan direksi perusahaan pada posisi setinggi-tingginya.

Lebih dari itu, lanjut Dahl, kelemahan keduanya adalah bahwa Mills telah gagal untuk memenuhi standar penelitian ilmiah karena ia tidak mampu membandingkan kekuasaan individu atau kelompok dalam berbagai kasus. Ketidakmampuan Mills untuk secara obyektif memilah dan mengkomparasikan dua entitas kekuasaan itu menjadikan kesimpulan penelitiannya tidaklah valid.

Kelemahan ketiga, Mills juga tidak bersungguh-sungguh berupaya menguji kasuskasus tertentu untuk mengetest hipotesa besarnya. Hipotesa besar dibiarkan saja menjadi hipotesa yang tidak teruji secara tuntas. Hasilnya adalah bahwa power elite theory yang dihasilkan tidak terlalu kuat secara akademik walaupun mendapatkan sambutan luar biasa di kalangan banyak pengamat.

Terakhir adalah bahwa dalam meneliti struktur kekuasaan Mills seharusnya menggunakan seluruh indikator kekuasaan itu sendiri; yakni indikator yang didasarkan pada kombinasi analisa jaringan (networking analysis)—khususnya "membership network analysis"-dan content analysis, untuk mendapatkan kesimpulan yang akurat (Luis, 2013).

Kritik tentang analisa jaringan dan analisa isi didasarkan pada metode penelitian struktur kekuasaan (power structure) yang disampaikan oleh William Domhoff. Menurutnya, penelitian struktur kekuasaan harus menggunalan network analysis dan content analysis untuk mendapatkan identifikasi keanggotaan analisi jaringan, jaringan interpersonal, jaringan organisasi, organisasi dan pola rekruitmen, ideologi, jaringan berpengaruruh, aliansi privat dan publik. Dengan data lengkap seperti ini maka spesifisitas struktur kekuasaan akan tergambar jelas dan obyektif. Sayangnya, dalam kenyataannya, Mills mencukupkan diri hanya pada dua indikator seperti disebutkan di atas.

Kritik-kritik pedas lainnya muncul dari pakar-pakar sosiologi lainnya, seperti Paul M. Sweezy, Herbert Aptheker, Tom Bottomore dan lainnya. Sweezy, misalnya, mengkritik ketidakkonsistenan Mills dalam analisa masalah. Ketika pada awalnya dia mengungkap tentang eksploitasi power elite atas masyarakat umum ternyata dalam analisanya Mills tidak memframing kajiannya dalam konteks eksploitasi. Dia gagal mengungkapkan sisi pertarungan antar kelas dengan secara langsung hanya menunjukkan bahwa perusahaan kaya memiliki posisi tinggi dan menentukan. Kegagalan ini disebabkan karena tidak digunakannya teori eksploitasi dalam kajian ini.

Kritik yang sama tentang hal ini muncul dari Alford dan Friedland yang dengan meyakinkan menyatakan bahwa ada ambiguitas teoritis dalam kajian Mills ini yang disebabkan oleh tiadanya teori societal contradictions of capitalism, Mills hanya bermain dengan retorika dan politik.

Lebih keras lagi adalah Tom Bottomore yang mengkritik ketidakseriusan Mills dalam buku The Power Elite ini. Di awal hipotesanya Mills menyatakan bahwa dia akan membuka lebar-lebar pertanyaan apakah power elite merepresentasikan sebuah kelas yang mengatur elite apa tidak. Ternyata, di bagian akhir buku ketika sampai pada pembahasan tentang itu, dia hanya berkata: "ini hanyalah upaya untuk menolak pendapat Marxist tentang the ruling class..." Pertanyaan tersebut akhirnya tidak didiskusikan secara serius.

Kelemahan lainnya adalah seperti yang dikemukakan oleh Aptheker bahwa setelah mengkaji buku ini terlihat jelas bahwa Mills tidak berupaya untuk menggunakan referensireferensi utama dalam bukunya ini, dalam 
bahasa Aptheker "Mills could have missed an already substantial body of empirical literature..." Konsekuensinya adalah banyaknya simplifikasi dan generalisasi dalam buku ini sehingga oleh sebagian pengamat dianggap kurang akurat.

Kritik pedas berikutnya adalah dari Poulantzas yang menyatakan bahwa buku The Power Elite Mills dan buku-buku sejenisnya sesungguhnya tidak menyajikan eksplanasi apapun tentang dasar kekuasaan politik. Tidak kalah keras dari kritik-kritik di atas adalah kritik Goran Therborn yang menyimpulkan bahwa " $C$. Wright Mills was not primarily a theoretician (C. Wright Mills sungguh bukan seorang teori)".

Kritik-kritik di atas adalah benar dalam hal bahwa ada titik-titik lemah dalam teori Mills. Keutuhan (comprehensiveness) dan kedalaman (intensiveness) makna dalam teori yang dikemukakannya tidak memenuhi standar dari sebuah teori sosial yang mapan. Sebuah teori yang mapan harus memiliki kesesuaian dan bisa dihubungkan dengan teori lainnya yang berkaitan. Pembacaan Mills akan teori sosial lainnya yang berkaitan sangatlah terbatas pada teori-teori dasar saja. Dalam konteks ini, teori elite C. Wright Mill memiliki kelemahan.

Akurasi, konsistensi dan keluasan cakupan teori dari teori elite C. Wright Mills ini juga perlu dicermati ulang, mengingat banyaknya sisi-sisi yang berkaitan dengan kelompok elite yang tidak dijadikan pertimbangan dalam pembuatan teori. Mungkin saja hal ini disengaja oleh Mills demi untuk menyederhanakan paparan teori, namun hal ini berimplikasi pada hilangnya beberapa faktor lainnya yang mungkin saja dalam sangat penting dalam menjelaskan the ruling class dan the ruled.

\section{PENUTUP}

Ada tiga kesimpulan utama yang bisa dikemukakan di sini dari uraian di atas: pertama, secara teoritis, perdebatan teori pluralism dan teori elite dalam kajian sosiologi politik begitu menyejarah sehingga tetap mewariskan "perang berkepanjangan" antar para pendukungnya. Ketika teori pluralisme menitikberatkan pada kebersamaan dalam membangun demokrasi, negara dan kekuasaan, teori elite mengungkap realita lain, yakni eksistensi kelompok elite minoritas yang sangat berpengaruh menentukan arah kebijakan kekuasaan dan negara. Kelompok elite ini minoritas dalam jumlah namum mayoritas dalam peran. Sementara massa umum (grass root society) adalah kelompok yang mayoritas dalam jumlah namun minoritas dalam peran. Kesimpulan kedua adalah bahwa C. Wright Mills dengan teori power elitenya mengemukakan dengan terbuka fakta yang ditemukannya tentang percaturan politik kekuasaan dan kepemerintahan di Amerika Serikat di mana masyarakat kelas bawah dan kelas menengah merupakan kelaskelas sosial yang dieksploitasi dan dimanipulasi oleh tiga kelompok elite yang dimanakannya power elite. Kelompok elite kuasa tersebut adalah terdiri dari, elite birokrasi, elite pengusaha dan elite militer. Mills memilih kata eksploitasi dan menolak kata dominasi untuk menggambarkan hubungan antar kelas di Amerika Serikat dengan alasan bahwa kata dominasi mengisyaratkan adanya kesamaan visi dan agenda. Kesimpulan ketiga adalah bahwa teori power elite ini tidaklah muncul tiba-tiba, melainkan memiliki geneologi intelektual dengan teori-teori sebelumnya, yakni teori elite klasik dan teori kelas Marxian dan Weberian. Di samping itu, ada faktor eksternal yang juga turut mendorong lahirnya teori ini, yaitu persaingannya dengan teori pluralisme. Persaingan teori dalam kancah akademik adalah sebuah anugerah, nukan sebuah petaka, karena dengannya akan selalu lahir teori lain yang menyanggah dan menyempurnakan.

\section{DAFTAR RUJUKAN}

Alford, R. R., \& Roger F. (1985). Powers of Theory: Capitalism, the State, and Democracy, Cambridge: Cambridge University Press.

Barrow, C. W. (2006). "Plain Marxist, Sophisticated Marxist, and C. Wright Mills' Power Elite," Makalah disampaikan pada pertemuan tahunan American Political Science Association, 
yang diadakan di Philadelphia, Pennsylvania, pada tanggal 31 Agustus sampai dengan tanggal 3 September 2006.

Baugut, P., \& Scherr, S. (2019). Should the Media Be More or Less Powerful in Politics? Individual and Contextual Explanations for Politicians and Journalists. Political Communication, $36(1)$ $127-148$. https://doi.org/10.1080/10584609.2018 .1517844

Borgatta, E. F., \& Rhonda J. V. (2000). Montgomery, Encyclopedia of Sociology vol. 3, Edisi 2, New York: MacMillan Reference USA,

--------, Encyclopedia of Sociology vol. 4, Edisi 2 New York: MacMillan Reference USA, 2000

Capano, G., Howlett, M., \& Ramesh, M. (2015). Bringing Governments Back in: Governance and Governing in Comparative Policy Analysis. Journal of Comparative Policy Analysis: Research and Practice, 17(4), 311-321. https://doi.org/10.1080/13876988.2015. 1031977

Coleman, J. W., \& Donald R. C. (1993). Social Problems, edisi 5, New York: HarperCollins College Publishers, Domhoff, G. William. "C. Wright Mills, Power Structure Research, and the Failures of Mainstream Political Science," dalam New Political Science No. 29

Haralambos, M. M. H., \& Robin H. (2000). Sociology Themes and Perspectives, edisi 5, London: HarperCollins,

Jennifer, N. (2002), "Review the Power Elite" di jurnal Economicus, vol. $\mathrm{V}$, Winter.
Langman, L. (2000) "History and Biography in a Global Age: The Legacy of C. Wright Mills," makalah yang disampaikan pada pertemuan tahunan American Sociological Association di Washington D.C., pada bulan Agustus.

Mills, C. W. (1990). Power Elite, Oxford: Oxford University Press,

Parker, R. (2005) "Five Theses on Identity Politica," dalam Harvard Journal of Law \& Public Policy Vol . 29

Parsons, T. (1966). "The Political Aspect of Social Structure and Process, " dalam David Easton (ed)., Varieties of Political Theory, Englewood Cliffs, New Jersey: Prentice-Hall.

Robertson, I. (1988). Sociology, edisi 3, New York: Worth Publishers, Inc.,

Sills, D. L. (1972). (ed.), International Encyclopedia of the Social Sciences vol. 5 London: Collier-MacMillan Publishers,

Spencer, M. (1993). Foundation of Modern Sociology, Scarborough, Ontario: Prentice Hall Canada Inc.,

Syam, N. (2005). Bukan Dunia Berbeda Sosiologi Komunitas Islam, Surabaya: Pustaka Eureka, http://www.maison.com/C Wright Mills [1916-62] at Maison d'Être Philosophy Bookstore.htm

Luis G. V. (2013) "Elites, political elites and social changein modern societies," dalam Revista de Sociologia No. 28.

Mills, C. W. (1963). "On Knowledge and Power," dalam Irving L. Horowitz (ed), Power, Politics and People, (New York: Ballantine Books,), 